710

日本機械学会論文集 (C 編)

76 巻 763 号 $(2010-3)$

論文 No.09-0838

\title{
リサイクル設計を考慮した衝撃リベット締結法*
}

\author{
木之下 広幸*1, 海 津 浩 一*2, 吉 原 智 啓*3 \\ 河村 隆 介*1, 池田清 彦*1
}

\section{Impact Riveting Considering Design for Disassembly}

\author{
Hiroyuki KINOSHITA*4, Koichi KAIZU, Tomohiro YOSHIHARA, \\ Ryuusuke KAWAMURA and Kiyohiko IKEDA

\footnotetext{
*4 Mechanical Systems Engineering, University of Miyazaki, Gakuenkibanadai-nishi Miyazaki-shi, Miyazaki, 889-2192 Japan
}

\begin{abstract}
In this paper, a new riveting method considering design for disassembly is attempted. The method can join the sheets by the high-speed blanking without drilling of the sheets as well as disjoin easily the jointed sheets. The joining is carried out by the following procedures: (1) A pair of a rivet with a rivet head and a rivet holder which has been already drilled in the center as the other rivet head is set on condition that their center axes may agree and two pieces of sheets are interposed between them. (2) The rivet axis set on the upper sheet is struck into sheets by the collision of the weight with high speed and the rivet axis penetrates the sheets. (3) The rivet axis which penetrated the sheets is inserted into the hole of the rivet holder and then the tip of the rivet axis which projects from the hole collides with a die. Then the axis and the rivet holder are joined because the plastic deformation of the axis generated by the collision fills up the hole of the rivet holder and the sheets are fastened tightly by both the rivet with the rivet head and the rivet holder. The experimental results showed that the joint strength by impact riveting was higher than that of caulking, and the deformation of sheets was small. In addition, the joined sheets could be disjoined easily.
\end{abstract}

Key Words: Machine Element, Fixing Element, Impact Riveting, Disassembly, Caulking, Joint Strength

\section{1. 緒 言}

近年, 自動車業界において, セルフピアシングリベ ツトが急速に用いられるようになっている(1)，(2)。 セルフピアシングリベットは, 板の穴あけ加工が不要, 接合速度が速い，溶接が難しい材料や異種材料の締結 が可能などの優れた特徴を持っている ${ }^{(3)}$. 一方, リべ ット締結後の状況から，あまり高い締結強度が得られ ないこと，締結部周辺の板の面外変形が大きいことが 欠点として挙げられる(4).

著者らはこれまでに，高速打抜き加工の研究 ${ }^{(5)}$ を行 い, 高速打抜き加工は，(1)打抜いた板の穴周囲の変形 が小さいこと，（2）打抜き速度が速いほど平滑なせん 断面の割合が大きいことを明らかにした。そして，高 速打抜き加工の特徴をリベット締結に活かすことを考

* 原稿受付 2009 年 9 月 18 日.

*1 正員, 宮崎大学工学部 (昰889-2192 宮崎市学園木花台西 11).

*2 正員, 兵庫)県立大学大学院工学研究科 ( $671-2280$ 姫路市 書写 2167).

*3 宮崎大学大学院工学研究科 (恶 889-2192 宮崎市学園木花台 西 1-1).

E-mail: t0d165u@cc.miyazaki-u.ac.jp
え，(1)板の穴あけ加工を必要としない，(2)締結強度が 高い，(3)締結後の板の面外変形が小さい，以上のこと を満足するリベット締結法の開発を目指し，通常のか しめ加工に用いられている形状に近いリベットを高速 で板八打ち込多，穴あけと板の締結を同時に行う単発 衝撃リベット締結法を提案した ${ }^{(6)}$.

この単発衝撃リベット締結法は他のリベット締結と 同様に永久締結を前提としており，組立部品（継手） を簡単には分解できない，そのため，部品交換が容易 ではない，また，近年の省資源化の要望とともに廃棄 組立部品をリサイクルできることが強く求められてい るが，同締結法は，廃棄組立部品のリサイクル性は悪 い，そこで本研究では，単発衝撃りベット締結法にお いて，後述するように新たにリベットホルダーを用い ることにより, 組立部品の分解が容易な締結法 (以後, このリベット締結法を衝撃リベット締結法 ${ }^{(7)}$ と呼ぶ) を開発し，アルミニウム合金板の締結に適用した。

本論文では，まず衝撃リベット締結法の概要と必要 な条件について述べる，次に衝撃リベット締結法を適 用して作製した継手の変形状態ならびに締結強度をか 
しめ加工により作製した継手のそれらと比較して検討 した。また，リサイクルを考虑して継手の分解試験を 行い，その分解性について検討した. それらの結果か ら，開発した衝撃リベット締結法の有効性を示した。

\section{2. 実 験 方 法}

\section{$2 \cdot 1$ 衝揧リベット締結法の概要図 1 は衝撃リ} ベット締結に用いた実験装置全体の概略図を示してい る. また，図 2 は衝撃リベット締結法に用いるリベッ ト,リベットホルダー, 重り, およびダイスの各寸法・ 形状を示している。本研究では図 1 に示す実験装置と 図 2 に示す各部品およびダイスを用いて，2枚重ねの 帯板を衝撃リベット締結法により締結した. 図 3 は作 製した継手の寸法・形状を示している，なお，図2に 示す各部品の寸法・形状は, 衝撃リベット締結の予備 実験を行うことにより最終的に決定したものである. 各寸法を決定した経緯については， $2 \cdot 2$ 節の試験片お よびダイスの設計において詳しく述べる. 以下に, 図 4 の衝撃リベット締結の概要図も参照して, 衝撃リベ ット締結法の手順を記述する.

(1) 図 1 のコンプレッサー (東芝製 SP14-22T7:L2-2kW)

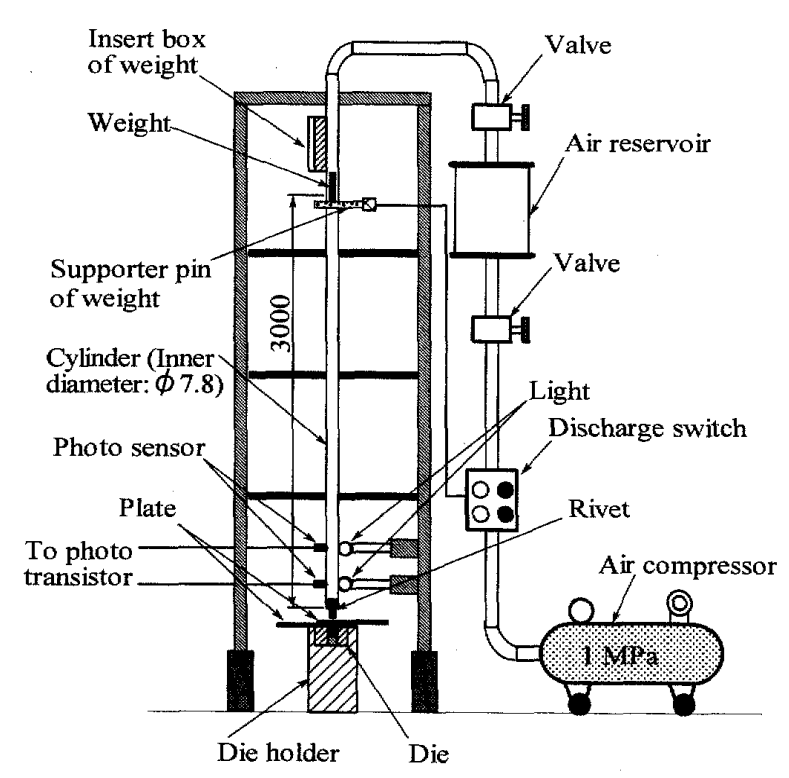

Fig.1 Experimental equipment

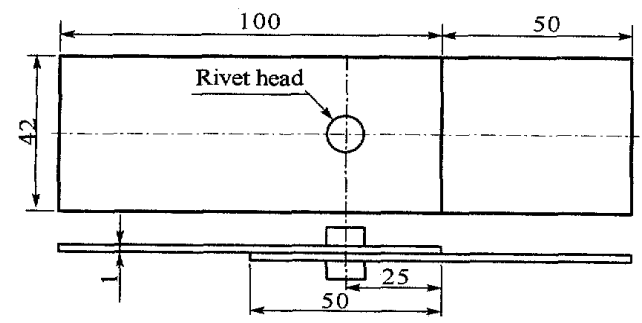

Fig.3 Dimension of joint
で蓄压タンクに $1 \mathrm{MPa}$ の圧縮空気を蓄圧する.また, 重りをシリンダ一上部に挿入し，支持ピンで落下し ない上うに支えておく。

(2) 図 2 に示すダイス内部に片方のリベット頭部とな るリベットホルダーを設置する，そして，図 4 (a) に示すように, シリンダー出口の直下にダイスと締 結対象の 2 枚の板を設置する. さらに, 板の上面に リベットを軸の先端が接する状態で設置する．シリ ンダー出口と板の間には, 重りが発射された際の空 気を逃すために約 $9 \mathrm{~mm}$ の隙間を設けている.

(3)図 4（b）に示すように，圧縮空気のバルブを開放 して重りをリベットに衝突させ, 重りの衝撃力によ りリベット軸が板を打抜くとともにダイス内部に 設置したリベットホルダーの穴に入る.さらに，リ ベット軸先端部がダイスと衝突して塑性変形する ことにより, リベット軸がリベットホルダーの穴内 に充満してリベットホルダーと結合し板を締結す る. なお，リベット軸により打抜かれた板の切断片 は, ダイス底部に排出される。

$2 \cdot 2$ 試験片およびダイスの設計＼cjkstart衝撃リベット 締結法により板を締結するためには，板材とリベット

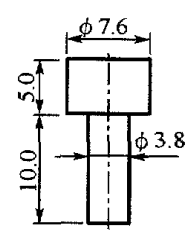

(a) Rivet

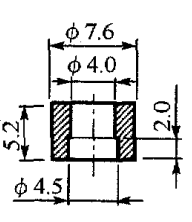

(b) Rivet holder

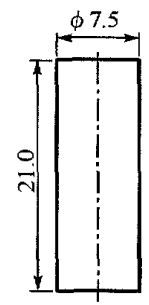

(d) Weight

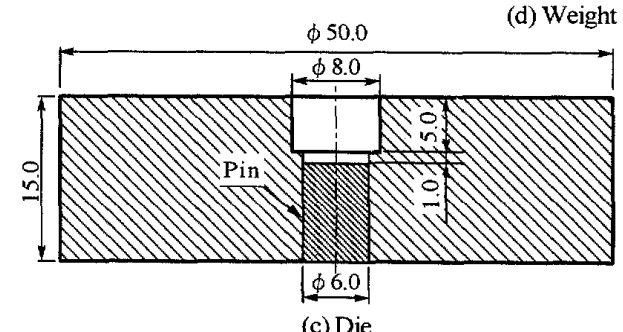

Fig.2 Shape and dimensions of rivets, rivet holder, die and weight

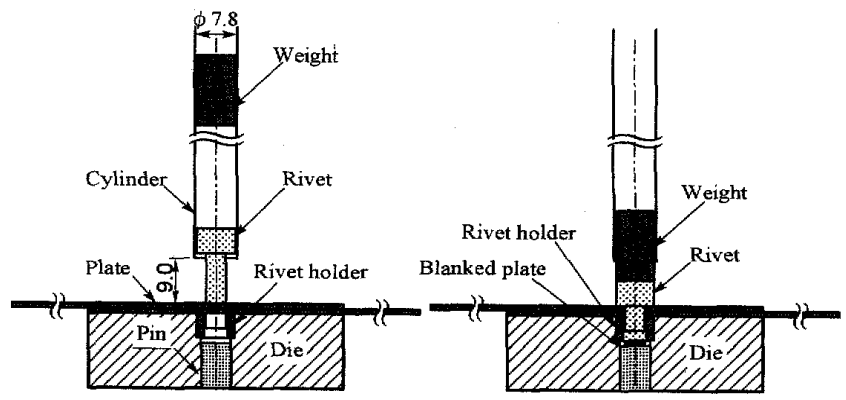

(a) (b)

Fig.4 Joining methods 
材の材質, リベット, リベットホルダー，ダイスの各 寸法，および重りの質量と衝突速度を適切に選定する 必要がある。これらは相互に関連して衝撃リベット締 結法の可否を左右するため, 本研究では予備実験を行 うことにより， 2 枚の板が強固に接合されていること を確認して, 各部品の最終寸法を決定した.

(1)板材とリベット材の材質本研究では, まず 厚さ $1 \mathrm{~mm}$ のアルミニウム合金 A1050P-H24 (0.2\%耐力： 約 $70 \mathrm{MPa}$ ) の板を締結対象とした. 次に, リベット軸 が板を打抜くためには，リベット材の変形抵抗が板材 の変形抵抗よりもある程度高いことが必要であるので, リベット材とリベットホルダーの材質にアルミニウム 合金 A5052Bd（0.2\%耐力：約 170MPa）材老選定した。

(2)リベットおよびリベットホルダーの寸法・形状

リベット (図 2(a)) は，かしめ加工に用いられてい る平リベットと類似した形状とし，頭部高さを $5 \mathrm{~mm}$, 頭部直径を $7.6 \mathrm{~mm}$ とした.リベットの軸直径と長さは 次のように決定した。通常のかしめ加工による楴結で は, リベット軸の直径と板厚の関係式 ${ }^{(8)}$ に基づいて, 厚さ $1 \mathrm{~mm}$ の板に対して，呼び径 $3 \mathrm{~mm}$ から $5 \mathrm{~mm}$ のリベッ トが用いられる，そこで，リベット軸の直径とリベッ トホルダーの穴直径を $4 \mathrm{~mm}$ 程度とし, まずリベットホ ルダーの最小の穴直径を $4.0 \mathrm{~mm}$ に固定した. そして, リベット軸の直径を $3.6 \mathrm{~mm}$ から $4.0 \mathrm{~mm}$ まで $0.1 \mathrm{~mm}$ 刻み で, リベットの軸長を $9.0 \mathrm{~mm}$ から $12.0 \mathrm{~mm}$ まで $1.0 \mathrm{~mm}$ 刻みで変化させて衝撃リベット締結の予備実験を行っ た。 その結果から，リベット軸の直径を $3.8 \mathrm{~mm}$ ，その 軸長を $10.0 \mathrm{~mm}$ と決定した。

リベットホルダー (図 $2(\mathrm{~b})$ ) は, リベットの頭部と 同じ外径とし，内部にはリベット軸とリベットホルダ 一の結合力を高应ために, 直径 $4.0 \mathrm{~mm}$ と $4.5 \mathrm{~mm}$ の 2 種類の穴を設けた.リベットホルダーの高さ $(5.2 \mathrm{~mm})$ は, ダイスの穴深さ $(5 \mathrm{~mm})$ よりも $0.2 \mathrm{~mm}$ だけ高くした. これは，リベットホルダーの高さとダイスの穴樑さを 同一にして, リベットホルダーの表面とダイスの表面 が同じ高さになるようにリベットホルダーをダイス内 部に設置した場合には，下側の板の締結部周辺にくぼ みが生じる傾向があった。このくぼみを生じさせない ためにリベットホルダーの高さをダイスの穴樑さより も僅かに高くした，以上のように寸法を決定したリべ ットとリベットホルダーは, 直径 $8 \mathrm{~mm}$ の棒材から切削 加工により所定の寸法に加工した.

（3）ダイスの寸法・形状 ダイス（図 2(c)）は, ダイス中心部にリベットホルダーを配置するための直 径 $8 \mathrm{~mm}$, 深さ $5 \mathrm{~mm}$ の穴を設け, さらに穴の底部に、リ ベット軸により打抜かれた板の切断片が排出されて回
収できるように直径 $6 \mathrm{~mm}$, 深さ $1 \mathrm{~mm}$ の穴を設けた。ま た，その穴の下部には，打抜かれた板の切断片を取り 出しやすくするためにピンを挿人した。ダイスおよび ピンの材質は, 冷間金型用鋼 SKD11 である。なお, 図 4 に示すように，ダイスはダイスの中心軸とシリンダ 一の中心軸が常に一致するように治具を用いてダイス ホルダーに設置される.

(4)重り 重り（図 2(d)）は, リベット軸が板を 打抜くことができる十分な打撃力があること，および リベットを打撃する際に大きな塑性変形や割れが生じ ないことの条件を満たす必要がある。本研究では，重 りの材質を冷間金型用鋼 SKD 11 とし, 寸法を直径 $7.5 \mathrm{~mm}$, 長さ $21 \mathrm{~mm}$, 重りの質量を $7.2 \mathrm{~g}$ とした. 締結実験は, 重りに約 48J の運動エネルギー（重りとリベットとの 衝突速度: 平均約 $115 \mathrm{~m} / \mathrm{s}$ ) を与えて, 重りをりベット に衝突させることにより行った。なお，本実験装置の 圧縮空気の圧力は一定(1MPa)であるが，重りの速度は 圧縮空気の開放と重りを放すタイミングをずらすこと により変えることができる.

(5)かしめ加エによるリベット継手の作製＼cjkstart衝撃 リベット締結法により作製した継手の変形状態ならび に締結強度を，かしめ加工により作製したリベット継 手のそれらと比較するために，かしめ加工によるリべ ット継手も作製した。衝撃リベット締結法により作製 した継手とかしめ加工により作製した継手を比較する 理由は, かしめ加工は最も汎用的な締結法であるとと もに，この方法で作製した継手は一般に締結強度が高 い(9) こと, かしめ加工による締結法および衝撃リベッ 卜締結法ともに，リベット軸の太りとリベット頭部同 士（リベット頭部とリベットホルダー）で板を締め付 けるので，基本的な締結のメカニズムが同じであるこ と，による. かしめ加工には，図 2(a)に示す衝撃り心゙ ット締結法に用いたリベットの軸長を $1 \mathrm{~mm}$ 増したリベ ットと，ドリルで $\phi 4.0$ の穴あけをした板を用いた. 板の締結は，リベット頭部を下向きに，リベット軸を 上向きに置き，リベット軸をフラットパンチにより 9800N の荷重で圧縮することにより行った，締結後の リベット頭部の直径は, リベット軸の約 1.7 倍の $6.4 \mathrm{~mm}$ である.このリベット頭部の直径は, 衝撃リベット締 結法に用いたリベットの頭部直径 $(7.6 \mathrm{~mm})$ よりもやや 小さいが，リベット頭を軸の約 1.6 倍から 1.7 倍の大 きさに成形するというリベット締結の条件 ${ }^{(8)}$ を満足し ている. また，通常のリベット締結では，リベットの 軸直径が $\phi 3.8$ 程度の場合, 板の穴の直径は $\phi 4.0$ 程度 とされているが，板に $\phi 4.5$ の穴あけをした継手も作 製し，強度試験に用いた。この継手は，板に $\phi 4.5$ の 


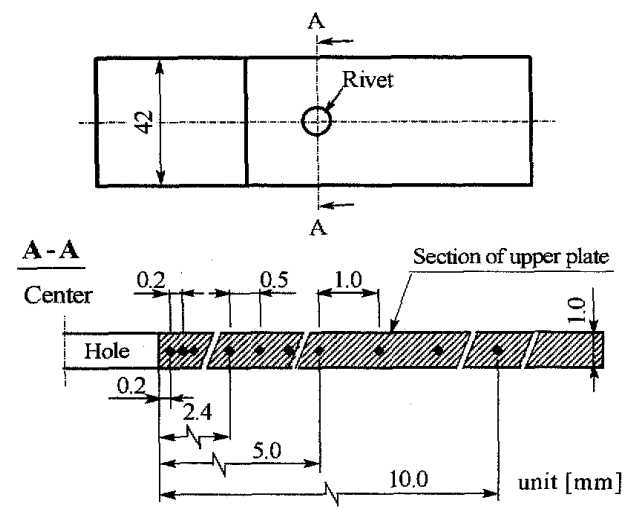

Fig.5 Hardness measurement

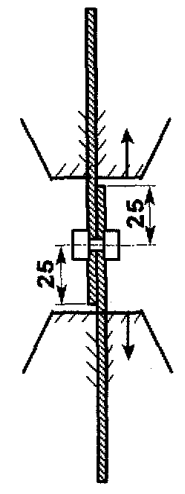

Fig.6 Tensile test of joint

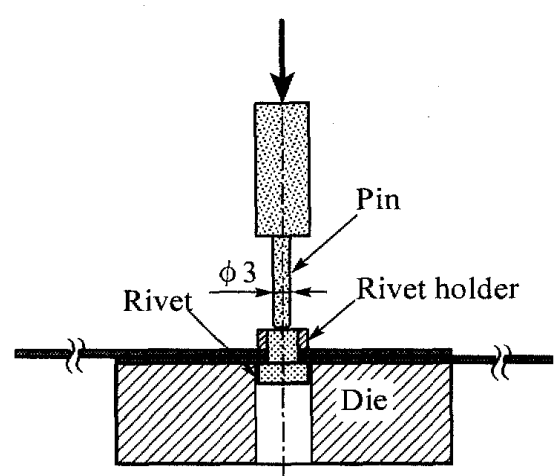

Fig.7 Disjoining method
穴あけをすることで，締結後のリベット軸の直径をよ り大きくしたものである. 継手に用いたリベットの寸 法・形状は同じであるが，この場合の締結後のリベッ 卜頭部の直径は $6.1 \mathrm{~mm}$ である. 板に $\phi 4.5$ の穴あけを して継手を作製した目的は，衝撃リベット締結法によ り作製した継手の強度とかしめ加工により作製した継 手の強度を締結後のリベット軸の直径がほぼ等しい状 態で比較するためである，特に，両者のリベット軸と 板穴の接触面におう注圧縮強さ（支圧強さ）をリベッ 卜軸の直径がほぼ等しい状態で検討するためである。

\section{$2 \cdot 3$ 重りの衝突速度の測定方法重りの衝突速} 度を求めるために，図 1 に示すように, シリンダーの 出口近くに二対の光源と光センサーを配置し, 重りが 通過する時の光量の変化を光センサ一で測定し, フォ トトランジスタを介してデジタルオシロスコープに記 録した. そして, 重りが $90.0 \mathrm{~mm}$ の光センサー間を通過 するのに要した時間から重りの衝突速度を求めた。

\section{4 帯板の締結部周辺の変位測定衝撃リベッ} 卜締結法およびかしめ加工により作製した継手の変形 状態を比較するために，継手の締結部付近の形状测定

（面外変位测定）を行った。测定にはCCD レーザ変位 計 (キ一エンス製 $\mathrm{LK}-\mathrm{G} 85$ : 精度 $0.2 \mu \mathrm{m}$, 基準距離 $80.0 \mathrm{~mm}$, 測定範囲士15.0mm) を用い，図 3 に示す継手の長手方 向中心線上の表面形状をリベットの中心から約 $25 \mathrm{~mm}$ の範囲内で測定した.

\section{5 硬さ測定の方法衝撃リベット締結法およ} びかしめ加工における板に及ぼす加工硬化の影響につ いて検討するために，板の締結部付近の硬さ測定を行 った. 硬さ測定には, マイクロビッカース硬度計(アカ シ製 MKV-H3）を用いた. 図 5 に硬さ測定位置を示す. 板の硬さ測定は, 継手を A-A 線に沿って切断し, 切断 した上側の板の断面上を測定することにより行った. 硬さ测定は，穴緣から0.2mm 離れた位置より開始し， 穴縁からそれぞれ，0.2m 以上 $2.5 \mathrm{~mm}$ 以下では $0.2 \mathrm{~mm}$
間隔， $2.5 \mathrm{~mm}$ 以上 $5.0 \mathrm{~mm}$ 以下では $0.5 \mathrm{~mm}$ 間隔， $5.0 \mathrm{~mm}$ 以上 $10.0 \mathrm{~mm}$ 以下では $1.0 \mathrm{~mm}$ 間隔で行った。

$2 \cdot 6$ リベット継手の引張試験作製した継手の 静的強度を検討するために，オートグラフ（島津製作 所製 $\mathrm{AG}-500 \mathrm{~A}$ ）を用いて引張試験を行った。図 6 は継 手の引張試験の概略図を示している，継手の引張試験 は，上下のチャックの余裕を利用して 2 枚の板が負荷 方向に平行になるようにつかみ， $1 \mathrm{~mm} / \mathrm{min}$ の速度で行 sた.

$2 \cdot 7$ リベット継手の疲労試験 引張試験と同様 に，作製した継手の疲労強度を検討するために，油圧 サーボ式試験機（島津製作所製 EHF-ED10-20L）を用い て継手の繰返し引張試験を行った。試験片のつかみ方 は，引張試験と同じである。疲労試験は，最大引張荷 重を継手の引張試験によって得られた最大引張荷重の 平均值よりも低い值に設定し，最小荷重をゼロに設定 して周波数 $20 \mathrm{~Hz}$ で行った。 また, 最大引張荷重の設定 值を徐々に下げて，継手が破断するまでの繰返し数が $10^{6}$ 程度に達するまで試験を行った。

2.8 継手の分解試験の方法 図 7 は衝撃リベッ ト締結法により作製した継手の分解方法の概要を示し ている，継手の分解は，板の面をダイスに固定し，直 径約 $3 \mathrm{~mm}$ のピンを用いてリベットホルダーと結合して いるリベット軸を押抜くことにより行った．分解試験 は，オートグラフを用いて $1 \mathrm{~mm} / \mathrm{min}$ の速度で行い，最 大押抜き力を継手の分解力として求めた.

\section{3. 実験結果および考察}

\section{$3 \cdot 1$ 衝撃リベット締結法によるリベットの締結状}

態図8は衝撃リベット締結法によって作製した継 手の一例を示している. 図は左から, 締結状態を打ち 込んだ向から見た場合, 締結状態を側面から見た場 合, 締結状態を裹面から見た場合を示している.また， 図 8(a)は重りの衝突速度が約 $115 \mathrm{~m} / \mathrm{s}$ の場合で, リべ 
ット軸が板を打抜くとともにリベットホルダーと結合 することにより，板を良好に締結している状態を示し ている.図8(b) は重りの衝突速度が約 $96 \mathrm{~m} / \mathrm{s}$ の場合で, リベット軸は板を打抜いてはいるが, 重りの衝突速度 が遅いため, リベット頭部と板との間に隙間が生じて いる状態を示している.このように, 衝撃リベット締 結法は, 重りの打撃力を利用して板の締結を行う方法 であるため, 板の締結状態は, 重りの運動エネルギー に依って変わる特性を持つ. 本研究では $7.2 \mathrm{~g}$ の重りを 用いているので，重りの運動エネルギーが約 $48 \mathrm{~J}$ の場 合に, 2 枚の板をかしめ加工と同じように衝撃リベッ 卜締結法により締結できることがわかる.

\section{$3 \cdot 2$ 締結部周辺の面外変形測定結果および硬さ測} 定結果図 9 は衝撃リベット締結法およびかしめ加 エにより作製した継手の断面形状を示している.また， 図 10 は継手の面外変形について検討するために, 締結 部付近の表面形状をレーザ変位計により測定した結果 を示している.図9および図10の (a) と (b)の比較から, 衝撃リベット締結法により作製した継手の面外変形は, 本研究の条件で作製したかしめ加工による継手の面外 変形よりも明らかに小さいことがわかる。なお，かし め加工により作製した継手は，締結時のかしめ力 (Riveting force) 減じることによって締結部付近の 変形を小さくすることができるが，かしめ力を減じる と締結強度が減少することになる ${ }^{(10)}$ 。一般に，かしめ 加工においては，板材よりも高い変形抵抗を持つリ心゙ ット材を用いた場合，リベット頭部を大きく成形する と, 締結部付近の変形が大きくなりやすいということ が課題である(10).

図 11 は板の締結部付近の硬さ分布を示している.か しめ加工により締結した板の硬さは，穴に近くなるに つれて徐々に高くなっており，板の加工硬化は，リベ ット頭外周部の直下付近（リベット軸の中心から約 $4 \mathrm{~mm}$ 程度）では小さく, 穴のごく近傍では大きい特徵 がある。このことは，図 9 の締結部の様相から，穴に 近いほど板の塑性変形が大きいことと対応している. 一方，衝撃リベット締結法による締結部では，硬さの 最大値はかしめ加工の場合とほとんで変わらないが, 硬さの分布はかしめ加工の場合と異なっており, リべ ット頭部直下のほぼ全域で板の加工硬化が認められる.

\section{3 引張試験による継手の強度＼cjkstart図 12 は衝撃リ} ベット締結法およびかしめ加工により作製した継手の 引張試験による静的強度の比較を示している．継手の 引張試験は各 10 本ずつ行っている.棒グラフの高さは 最大引張荷重の平均值を表し，エラーバーが示す範囲 は標準偏差を表している．また，かしめ加工により作

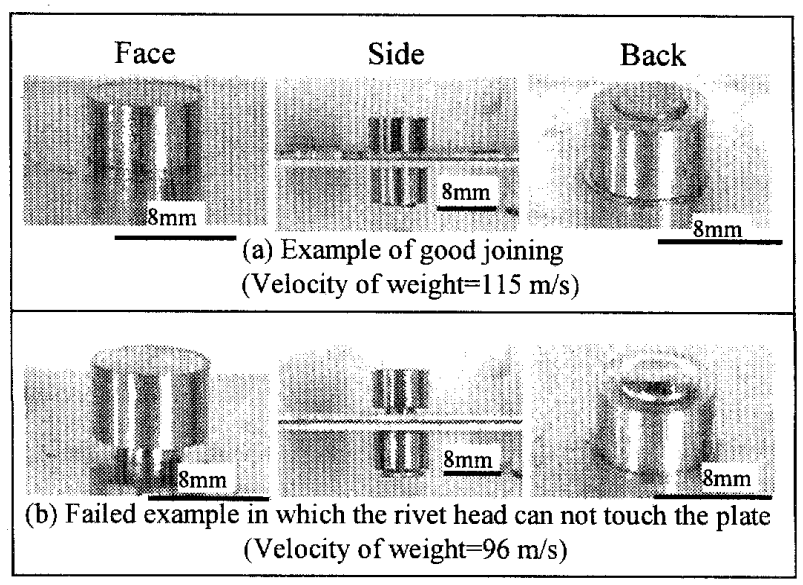

Fig.8 Aspects of riveting

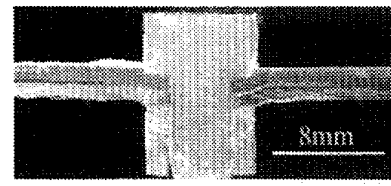

(a) Joint by impact riveting (Velocity of weight $=113 \mathrm{~m} / \mathrm{s}$ )

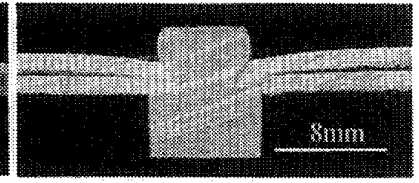

(b) Joint by caulking (Riveting force $=9800 \mathrm{~N}$, Rivet hole: $\phi 4.0$ )
Fig.9 Section of joint

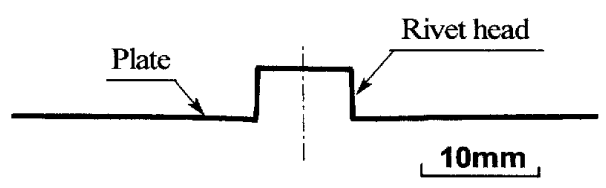

(a) Joint by impact riveting (Velocity of weight: $115 \mathrm{~m} / \mathrm{s}$ )

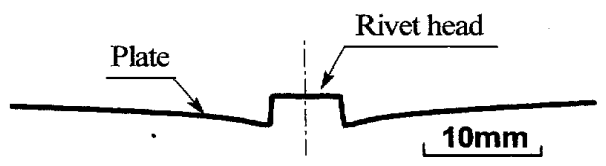

(b) Joint by caulking

(Riveting force: $9800 \mathrm{~N}$, Rivet hole: $\phi 4.0$ )

Fig.10 Configuration of the fastening part of joint

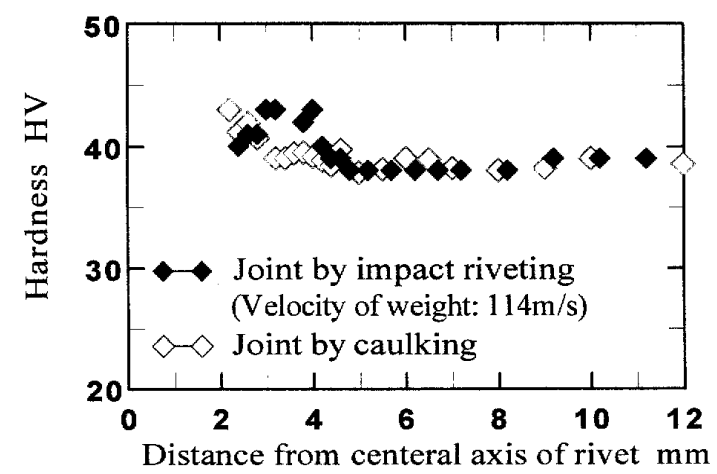

Fig.11 Hardness around the fastening part of plates 
製した継手に関しては，板に $\phi 4.5$ の穴あけをして作 製した継手の引張試験の結果も示している。この図か ら，衝撃リベット締結法は，かしめ加工よりも締結強 度が高く, 締結強度のばらつきも小さいことがわかる.

\section{4 疲労試験による継手の強度 図 13 は継手の} 疲労試験によって得られた負荷（最大引張荷重）と破 断に至るまでの繰返し数との関係を示している.なお, かしめ加工により作製した継手の疲労試験は，3・3 節 の引張試験による継手の強度評価の結果から, 締結強 度が高い方の継手（板に $\phi 4.5$ の穴あけをして作製し た継手)についてのみ行った.

継手は図 14 に示すように, どちらの締結法も板の穴 周囲がリベット軸によって圧縮されることにより徐々 に拡大して破壊している. 図 13 から, 衝撃リベット締 結法により作製した継手の疲労強度は，引張試験によ る静的強度と同様に，かしめ加工により作製した継手 の疲労強度よりも明らか涪くなっている，この理由 については，次のように考えられる。

一般に，リベット継手の破壊は，リベットがせん断 されて破壊する場合と板の穴周囲がリベット軸によっ て圧縮破壊される場合に分けられる ${ }^{(11)}$ ，(12)．本研究 のように板の穴周囲がリベット軸によって圧縮破壊さ れる場合は, 継手の強度は式 (1)で表されるリベット軸 と板穴の接触面における圧縮強さ（支圧強さ） $F$ と楴 結後のリベット頭部の締めつけ力によって生じる板と 板との閒の摩擦力の和になる ${ }^{(10) ，(12) . ~}$

$$
F=\sigma \cdot d \cdot t
$$

ここで， $\sigma$ はリベット軸と穴の接触面における圧力 で板の変形抵抗に传存して決まる，dはリベット軸の 直径, $t$ は板厚を表す.

まず，それぞれの継手の支圧強さについて検討する と, 図 11 の硬さ測定の結果から,板の穴周辺の硬さは, 穴の近傍を除いて衝撃りベット締結法の方が相対的に 高い.このことから, 板の穴周辺の変形抵抗は衝撃り ベット締結法の方が相対的に大きいと考えられる. 従 って, リベット軸と板穴の接触面における圧縮強さが 衝撃リベット締結法の方が大きいことが強度の高い原 因と考えられる。 なお, 図 9 に示すように，かしめ加 エにより作製した 2 種類の継手においては,板に $\phi 4.5$ の穴あけをして作製した継手の方が強度は高い。この 理由は, 締結後のリベット軸の直径が大きく, 支圧強 さが大きいためと考えられる.

次に，板と板との閒の摩擦力について検討する. 図 9(b)の締結部断面の状況から，かしめ加工ではリベッ 卜頭を成形することにより，板の穴縁から外側に徐々 に板を締めつけていくため, 板の穴縁に近い部分はリ

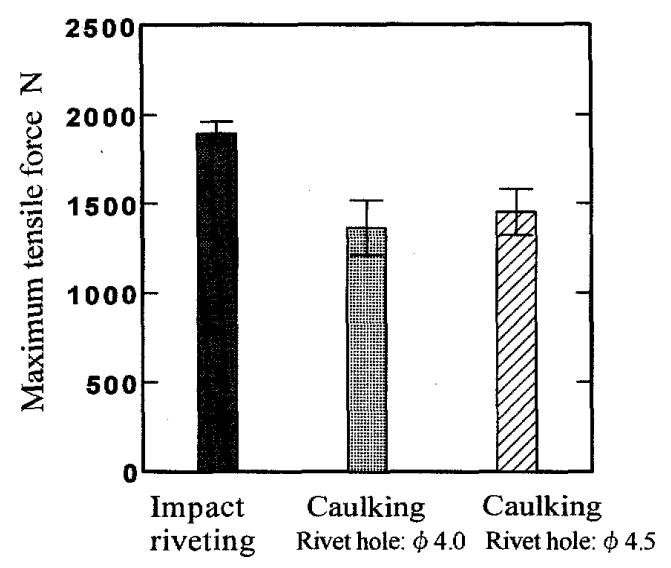

Fig.12 Tensile strength of joint by impact riveting and joint by caulking

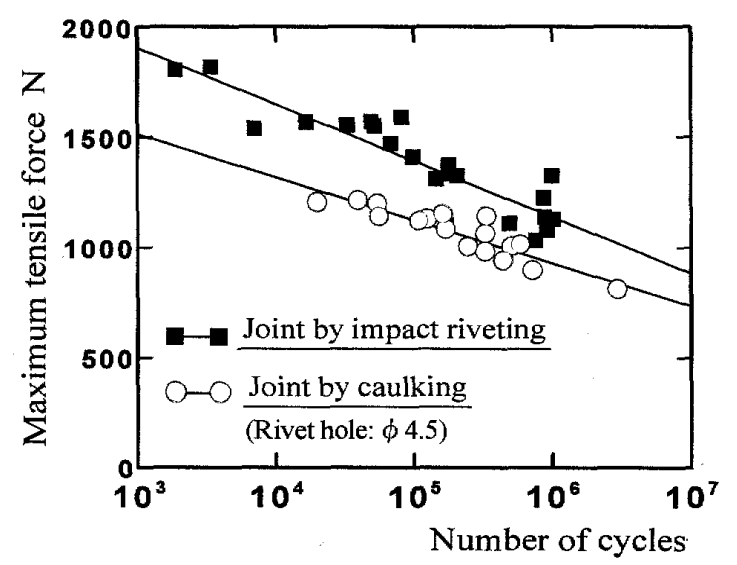

Fig.13 Fatigue strength of joint by impact riveting and joint by caulking

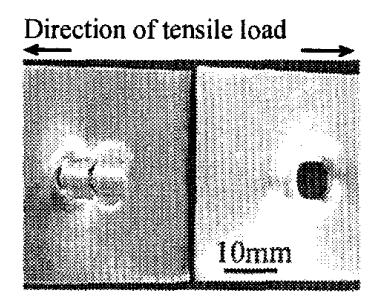

Maximum tensile load: $1818 \mathrm{~N}$ Number of cycles: 3422

(a) Joint by impact riveting (Velocity of weight $=118 \mathrm{~m} / \mathrm{s}$ )

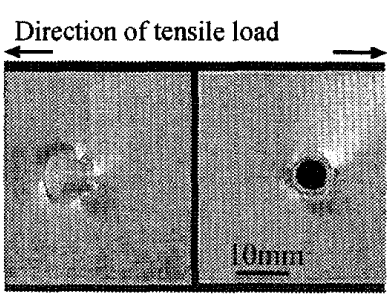

Maximum tensile load : $1210 \mathrm{~N}$, Number of cycles: 40030

(b) Joint by caulking (Riveting force $=8000 \mathrm{~N}$ )
Fig.14 Aspects of fractured joint
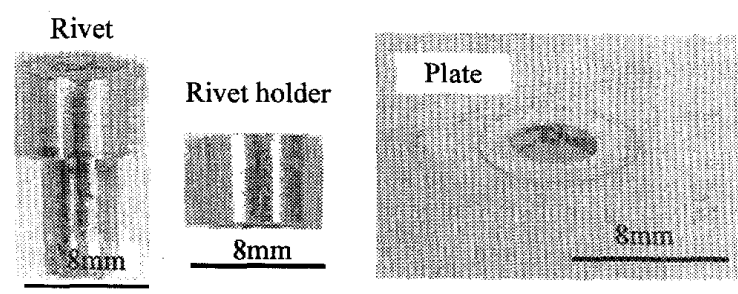

Fig.15 Aspects of disjoined rivet, rivet holder and plate 
ベット頭部により強く締めつけられているが，リベッ 卜頭部の外周部付近ではあまり締めつけられていない. このことは, 図 11 に示すかしめ加工に怙ける締結部周 辺の硬さ分布からも推察できる. 一方, 衝撃リベット 締結法では, 図 9(a)の状況から, 板はリベット頭部と リベットホルダーにより，かしめ加工の場合よりも広 い領域で一様に締めつけられているように観察される。 この結果から, 衝撃リベット締結法により作製した継 手の方が，かしめ加工により作製した継手よりも締結 後の板の締めつけ力が大きく, 継手が引つ張られた際 に板と板との間の摩擦力が大きくなったことも考えら れる。

\section{5 締結後の継手の分解試験の結果 㘠 15 は衝} 撃リベット締結法により作製した継手に対してピンを 用いてリベット軸を押抜くことにより分解した後のリ ベット，リベットホルダー，および板の様相を示して いる. 5 本の継手を分解するのに必要な押抜き力の平 均值は，約 $1500 \mathrm{~N}$ であった：これらの図から，本研究 で用いた単純な手法により，板を大きく変形させるこ となく継手を分解できることがわかる．また，分解後 の板の変形が小さいことから，板を再利用しやすいも のと考えられる.

最後に，本研究では高速の重りをリベットに衝突さ せ，その衝撃荷重により板に穴をあけ，かつ締結する 方法を用いた，その理由は，緒言でも述べた通り，板 の打抜き加工速度が締結部周辺の変形状態や板の機械 的性質に大きく影響を及ぼすと考えたからである。リ ベットに静的な圧縮荷重を作用させて板に穴をあけ， 締結する力法も可能と考えられるが，乙の場合の締結 部周辺の変形状態や継手の強度は条件が異なるため不 明である.この方法については，本研究の次のステッ プとして取り組んでいく所存である.

\section{4. 結言}

本研究では，継手の分解が容易な衝撃リベット締結 法を開発し，アルミニウム合金リベットを用いてアル ミニウム合金板材を締結した。そして継手の変形状態, 強度，および分解性について検討した，得られた結果 は次の通りである。
(1) 衝撃リベット締結法によりアルミニウム合金板材 の締結が可能であるとともに, 締結した継手に対し て，リベッ下軸を押抜くことにより，板を大きく変 形させずに分解が可能である.

(2)かしめ加工により作製した継手と衝撃リベット締 結法により作製した継手の比較から, 衝撃リベット 締結法は締結部付近の面外変形が小さい加工法で ある。

(3)衝撃リベット締結法により作製した継手の強度は, 本研究の締結条件におらいて,かしめ加工により作製 した継手の強度よりも高い。

\section{参 考 文 献}

(1) Takaki, Y. and Masuda, T. and Yasunaga, S., State of the Art : Application Technologies for Aluminum Alloys Sheet used in Auto Body Panels, KOBE STEEL ENGINEERING REPORTS, Vol. 54, No.3(2004), pp. $42-46$

(2) Inaba, T., Yamashita, H., Takebayashi, Y., Minoura, T. and Sasabe, S., Aluminum Product Application Technologies for Automobiles , KOBE STEEL ENGINEERING REPORTS, Vol. 55, No.2 (2005), pp. 66-74

(3) Kato, T. Abe, Y., Mori, K. and Xaun, W., Joining of Aluminum Alloy and Mild Steel Sheets by Self-Piercing Rivet, Journal of the JSTP, Vol.47, No.541 (2006) , pp. 119-123

(4) Lorenzo, G. Di and Landolfo, R., Shear experimental response of new connecting systems for cold-formed structures, Journal of Constructional Steel Research, Vol.60 (2004), pp. 561-579

(5) Kaizu, K., Blanking Method by Critical impact velocity, FORM TECH REVIEW, Vol.11, No.1, (2002), pp.63-67

(6) Kaizu, K., Kinoshita, H., K. Tsutsui, K. and IKEDA: K., Development of a Single Impact Riveting Method, Journal of Materials Science, Vol.57, No.7(2008), pp. 712-717

(7) Kaizu, K., Kinoshita, H. and Ikeda, K., Impact rivet, Japanese Patent Pending: 2007-151711

(8) Masuko, M., Machine Design, (1985), pp.71-92, Yokendo Co. Ltd.

(9) Nagai, Y., Riveting for chassis frame of automobile, Journal of the JSTP, Vol.38, No.441(1997), p.932-934

(10) Kinoshita, H., Kaizu, K., Toyama, M., Sato, M., Tokunaga, $\mathrm{H}$. and Ikeda, K., Proposal and effect of riveting process using the washer, Transactions of the Japan Society of Mechanical Engineers, Series. C , Vol.74, No.745 (2008), pp. 2281-2288

(11) Watanabe, N., Bridge Engineering, (1974), p.260-261, Asakura Publishing Co. Ltd.

(12) Simada, S., Design of steel structure (Rivet joint), http://www.nakanihon.co.jp/gijyutsu/Shimada/shimadatop. html 